\title{
Prevalence of Clostridium spp. and Clostridium difficile in Children with Acute Diarrhea in São Paulo City, Brazil
}

\author{
Claudia EA Ferreira $^{++}$, Viviane Nakano, Edison L Durigon, Mario J Avila-Campos ${ }^{+}$
}

\begin{abstract}
Laboratório de Anaeróbios, Departamento de Microbiologia, Instituto de Ciências Biomédicas, Universidade de São Paulo, 05508-900 São Paulo, SP, Brasil
\end{abstract}

Species of Clostridium are widely distributed in the environment, inhabiting both human and animal gastrointestinal tracts. Clostridium difficile is an important pathogen associated with outbreaks of pseudomembranous colitis and other intestinal disorders, such as diarrhea. In this study, the prevalence of Clostridium spp. and C. difficile, from hospitalized children with acute diarrhea, was examined. These children were admitted to 3 different hospitals for over 12 months. Eighteen (20\%) and 19 (21\%) stool specimens from children with (90) and without (91) diarrhea respectively, were positive to clostridia. Only $10 \mathrm{C}$. difficile strains were detected in $5.5 \%$ of the stool samples of children with diarrhea. None healthy children (without diarrhea) harbored C. difficile. From these $10 \mathrm{C}$. difficile, 9 were considered as toxigenic and genotyped as $\mathrm{tcdA}^{+} / \mathrm{tcdB}^{+}$or $\mathrm{tcdA}^{-} / \mathrm{tcdB}^{+}$, and 1 strain as nontoxigenic $\left(\mathrm{tcd} \mathrm{A}^{-} / \mathrm{tdcB}^{-}\right)$. They were detected by the citotoxicity on VERO cells and by the multiplex-polymerase chain reaction. Thirty clinical fecal extracts produced minor alterations on VERO cells. The presence of C. difficile as a probable agent of acute diarrhea is suggested in several countries, but in this study, the presence of these organisms was not significant. More studies will be necessary to evaluate the role of clostridia or $\mathrm{C}$. difficile in diarrhoeal processes in children.

Key words: Clostridium difficile - acute diarrhea - toxins - diagnosis - São Paulo - Brazil

Few data are available concerning Clostridium inhabiting human gastrointestinal tract, and the interest for these organisms is due to acute diarrhea in children, and to colon cancer etiology (Falk et al. 1998, Freeman \& Wilcox 1999).

Clostridium spp. are widely distributed in the environment. They are heterogeneous Gram-positive rods, anaerobic, fermentative, and spore forming inhabiting the human intestinal indigenous microbiota (Rocha et al. 1999).

Clostridia are distributed in 5 groups: group I, $C$. perfringens, C. septicum, C. novyi (type A), C. bifermentans, $C$. histolyticum, $C$. sordellii, related to mionecrosis or gas gangrene; group II, C. tetani, which causes tetanus; group III, C. botulinum, cause botulism; group IV, $C$. difficile, which causes acute diarrhea antibiotic-associated and pseudomembranous colitis; group V, C. perfringens, C. ramosum, C. bifermentans, and others linked to cerebral abscesses, abdominal and gynecologic infections, pneumonia, and bacteremies (Delost 1997).

C. difficile is an important nosocomial pathogen and is associated to outbreaks of pseudomembranous colitis (PMC) and other intestinal disorders, such as diarrhea in children and adults, although its role in the pathogenesis of gastroenteritis is not clear yet. However, it has been observed an association between the detection of $C$.

This work was partially financed by Fundação de Amparo à Pesquisa do Estado de São Paulo, Proc. 99/06475-1.

+ Corresponding author. Fax: + 55-11-3091.7344. E-mail: mariojac@usp.br

${ }^{++}$Fellowship of the Conselho Nacional de Desenvolvimento Científico e Tecnológico

Received 17 September 2002

Accepted 9 April 2003 difficile toxin from stools and a previous treatment with antibiotics in children over 12 months old (Freeman \& Wilcox 1999).

In Brazil, only a small number of clinical laboratories are able to reach a definitive diagnosis of $C$. difficile infection, maybe because simple reliable assays for toxins in isolates are not available. The major recognized cause of antibiotic-associated colitis is the cytotoxigenic $C$. difficile (Bartlett 1984). C. difficile produces 2 toxins: A (enterotoxin) and B (cytotoxin), which are the major virulence factors of this organism and which are encoded by 2 separated genes located in close proximity on the chromosome (Karasawa et al. 1999). Toxin A causes fluid accumulation and mucosal damage in several animal models (rabbit ileal and colonic loops), as well as in hamster cecal segments and in mouse and rat intestines (Lyerly et al. 1985). Toxin B has no enterotoxic activity, but it is a more potent cytotoxin than toxin $\mathrm{A}$ in tissue culture line by approximately 1,000-fold (Banno et al. 1984).

Several methods are presently available for the laboratory diagnosis of $C$. difficile-associated diarrhea (CDAD), including cell culture assay to detect the presence of cytotoxin, anaerobic culture of stool specimens for the organism followed by tests of the production of toxin (toxigenic culture), latex agglutination to $\operatorname{detect} C$. difficile-associated antigen in stools, and enzyme immunoassays (ELISA) to detect toxin A, toxin B or both (Knoop et al. 1993), but none of these methods have been able to offer, in an easy and quick way, a high sensitivity and specificity of test performance (Peterson et al. 1996). Recently, it has been developed a multiplex-polymerase chain reaction (PCR), which amplifies simultaneously toxins $\mathrm{A}$ and $\mathrm{B}$ genes and which can be used to distinguish both toxigenic and non-toxigenic $C$. difficile (McMillin et al. 1992). 
In this study, the presence of Clostridium spp. and toxigenic $C$. difficile strains from stool samples of hospitalized children with acute diarrhea was examined.

\section{MATERIALS AND METHODS}

Patients and sample collection - From June 2000 to June 2001 a total of 181 stool samples were collected from 90 children with acute diarrhea and 91 children without diarrhea. Children aged 0-5, neither sex nor race distinguished, were selected. Patients with acute diarrhea were hospitalized at Hospital Infantil Darcy Vargas, Hospital Universitário at the Universidade de São Paulo and Hospital Infantil Cândido Fontoura (São Paulo, SP, Brazil). Diarrhea was defined as 3 loose stools per day, at least, for 2 days. Some patients were given an antibiotic therapy (penicillin, oxacillin, erythromycin, cephalexin, trimetropin, amikacin, chloramphenicol, amoxicillin). Healthy children (without diarrhea), at the same age group, were selected from a day-care center, as control. Stools from both studied groups were naturally obtained and immediately processed. The Ethic Commission of the hospitals and of the Instituto de Ciências Biomédicas, USP (Parecer 097/CEP) approved this study.

Bacterial isolation and identification - Stools were streaked on a selective cycloserine cefoxitin fructose agar (CCFA) (George et al. 1979) and incubated in anaerobic conditions $\left(90 \% \mathrm{~N}_{2} / 10 \% \mathrm{CO}_{2}\right)$, at $37^{\circ} \mathrm{C}$, for 5 days. Approximately 8 to 9 characteristic colonies of each sample, showing a yellow fluorescence under ultraviolet light, were subcultured onto blood agar, and isolates were presumptively identified (Gram stain; lipase, lecithinase, catalase, $\mathrm{H}_{2} \mathrm{~S}$, and indole production; gelatin, esculin and starch hydrolysis, and localization of spores). Definitive identification was performed by the fermentation of glucose, fructose, lactose, maltose and sucrose, in peptoneyeast extract (PY) broth (Holdeman \& Moore 1977).

Cytotoxicity assay - Bacterial cytotoxicity was assayed on VERO (African green monkey kidney) tissue culture monolayers (Gulke et al. 2001). Cells were grown in a 96well microtitration plate (Corning, USA) with L15 minimal medium (Cultilab Ltd.) added of $2 \%$ fetal bovine serum, and incubated in air with $5 \% \mathrm{CO}_{2}$, at $37^{\circ} \mathrm{C}$, for $48 \mathrm{~h}$. All the 181 fecal extracts were prepared by mixing $0.5 \mathrm{ml}$ of stool and $1 \mathrm{ml}$ of phosphate buffered saline (PBS, pH 7.2), and by centrifugation $(6,000 \mathrm{~g}, 15 \mathrm{~min})$. Supernatants were filtered through $0.45 \mu \mathrm{m}$ membrane filter (Millipore Corporation, Bedford, Mass). In addition to this operation, all the isolated clostridia were grown in brain-heart infusion (BHI), and they were centrifuged $(13,000 \mathrm{~g}, 5 \mathrm{~min})$. Supernatants were filtered through $0.45 \mu \mathrm{m}$ membrane filters (Millipore) (Gilligan et al. 1993). Stool or supernatant filtrates (50 $\mu$ ) were added, in duplicate, to VERO cells. After a 2-day incubation in air- $5 \% \mathrm{CO}_{2}$ at $37^{\circ} \mathrm{C}$, the results were compared with control cells, to which $50 \mu 1$ of PBS had been added. Cytotoxicity was considered when the presence of affected cells was detected. A cytotoxic reference strain C. difficile VPI $10463\left(t c d A^{+} / t c d B^{+}\right)$, kindly provided by Dr Felicja Meisel Mikolajczyk (Department of Medical Microbiology, Center of Bio-structure Research, Poland) was used as control.
Detection of tcdA and tcdB genes - Chromosomal DNA was extracted from toxigenic $C$. difficile and non-toxigenic clostridia grown on blood agar. Bacteria were mixed with $300 \mu$ of sterilized Milli-Q water and washed twice at 12,000 $\mathrm{g}$, for $10 \mathrm{~min}$. Pellet was resuspended in $300 \mu \mathrm{l}$ of Milli-Q water and boiled for $17 \mathrm{~min}$. After centrifugation $(14,000$ $\mathrm{g}, 10 \mathrm{~min}$ ), supernatant was saved and used as template (McMillin et al. 1992). Positive (C. difficile VPI 19463) and negative control strains of toxigenicity were included in PCR assays.

Multiplex-PCR reaction - The primers used were: ToxA1 (5'-GGA AAT TTA GCT GCA GCA TCT GAC-3'); Tox-A2 (5'-TCT AGC AAA TTC GCT TGT GTT GAA-3'); Tox-B1 (5'-GGT GAT ATG GAG GCA TCA CCA CTA G$3^{\prime}$ ) and Tox-B2 (5'-TCC AGG ATA AGT CTC CTC TAC GTT G-3') (McMillin et al. 1992) (Gibco BRL Technologies). These primers amplified a characteristic 1,217-bp toxin $\mathrm{A}($ gene $t c d A$ ) and 1,050-bp toxin B (gene $t c d B$ ) bands. DNA amplification was performed in a final volume of $25 \mu \mathrm{l}$ containing 10X PCR Buffer (Gibco), $50 \mathrm{mM}$ $\mathrm{MgCl}_{2}, 10 \mathrm{mM}$ dNTP mix, $0.4 \mu \mathrm{M}$ each primer, $0.5 \mathrm{U} / \mu \mathrm{l}$ Taq polymerase, and $10 \mathrm{ng}$ DNA template. Amplification was performed in a DNA thermal cycler (Perkin Elmer, GenAmp PCR System 9700), programmed for $94^{\circ} \mathrm{C}(5 \mathrm{~min})$ followed by 37 cycles of $94^{\circ} \mathrm{C}(30 \mathrm{sec}), 50^{\circ} \mathrm{C}(30 \mathrm{sec})$ and $72^{\circ} \mathrm{C}(30 \mathrm{sec})$, and then $72^{\circ} \mathrm{C}(5 \mathrm{~min})$, in order to allow the completion of DNA extension.

Detection of amplified products - PCR products were detected by electrophoresis in 1\% agarose gel in $1 \mathrm{X}$ TBE (Gibco), at $70 \mathrm{~V}$, for $2 \mathrm{~h}$, stained with ethidium bromide $(0.5$ $\mu \mathrm{g} / \mathrm{ml}$ ), and photographed on a UV transilluminator (Electrophoresis Documentation and Analysis System 120, Kodak Digital Science). A molecular mass standard of 1 $\mathrm{Kb}$ DNA ladder (Gibco) was included.

\section{RESULTS}

Recovery of clostridia from feces samples - The prevalence of clostridia and $C$. difficile isolated from children with acute diarrhea is showed in Table I. In Table II it can be observed the isolation of $C$. difficile from stools of hospitalized children of different ages.

\section{TABLE I}

Distribution of clostridia in 37 stool samples from children with and without diarrhea

\begin{tabular}{lcccc}
\hline & \multicolumn{4}{c}{ Stool samples } \\
\cline { 2 - 5 } Species & $\begin{array}{c}\text { Diarrhea } \\
(n=18)\end{array}$ & $\%$ & $\begin{array}{c}\text { Normal } \\
(n=19)\end{array}$ & $\%$ \\
\hline Clostridium difficile & 5 & 28 & 0 & 0 \\
C. septicum & 1 & 5.6 & 4 & 21.1 \\
C. bifermentans & 0 & 0 & 1 & 5.3 \\
C. ramosum & 9 & 50 & 8 & 42.1 \\
C. barattii & 0 & 0 & 4 & 21.1 \\
C. butyricum & 1 & 5.6 & 2 & 10.5 \\
C. clostridioforme & 1 & 5.6 & 1 & 5.3 \\
C. innocuum & 1 & 5.6 & 2 & 10.5 \\
C. sphenoides & 0 & 0 & 2 & 10.5 \\
C. paraputrificum & 0 & 0 & 1 & 5.3 \\
Clostridium sp. & 3 & 16.6 & 0 & 0 \\
C. limosum & 2 & 11.1 & 0 & 0 \\
\hline
\end{tabular}


TABLE II

Isolation of Clostridium difficile from stool samples of 90 hospitalized children of different age groups

\begin{tabular}{lccc}
\hline & \multicolumn{3}{c}{ Children with diarrhea } \\
\cline { 2 - 4 } Age & $n$ & $\%$ & C. difficile \\
\hline Newborn - 5 months & 44 & 4.5 & 2 \\
6 - 11 months & 22 & 9.1 & 2 \\
$1-$ 5 years & 24 & 4.2 & 1 \\
\hline Total & 90 & 5.5 & 5 \\
\hline
\end{tabular}

C. difficile toxin detection and presence of toxin genes - Nine $C$. difficile strains showed cytotoxic activity on VERO cells, producing typical alterations such as increase of size and rounding of cells. Only one $C$. difficile strain did not show neither cytotoxic activity, nor toxin A or B genes. Thirty stool extracts showed cytotoxicity, including those from which $C$. difficile were isolated. Other strains as C. ramosum (23), C. septicum (7), C. barattii (4), C. butyricum (3), C. clostridioforme (2), C. limosum (3), C. bifermentans (1), C. innocuum (1), C. paraputrificum (1), Clostridium sp. (1), and C. sphenoides (1), produced slight alterations on VERO cells, differently from those produced by $C$. difficile, which become the cells oval without altering their size (data not shown).

Both the presence and the absence of $C$. difficile toxin genes were examined by multiplex-PCR. Only $6 C$. difficile carried both the toxin $\mathrm{A}$ and $\mathrm{B}$ genes, 3 strains carried only the toxin B gene and 1 strain did not carry any gene (Table III). Other species of Clostridium, differently from C. difficile, did not carry any toxin gene.

TABLE III

Cytotoxicity on Vero cells and genotypes of Clostridium difficile recovered of children with diarrhea

\begin{tabular}{|c|c|c|c|c|}
\hline \multirow[b]{2}{*}{ Strain } & \multirow{2}{*}{$\begin{array}{c}\text { Vero } \\
\text { cytotoxicity }\end{array}$} & \multicolumn{2}{|c|}{ Genes $^{a}$} & \multirow[b]{2}{*}{ Genotypes } \\
\hline & & $\overline{t c d A}$ & $\overline{t c d B}$ & \\
\hline $\mathrm{P} 2$ & - & - & - & $t c d A^{-} / t c d B^{-}$ \\
\hline P3 & + & - & + & $t c d A^{-} / t c d B^{+}$ \\
\hline P27A & + & + & + & $t c d A^{+} / t c d B^{+}$ \\
\hline P27C & + & - & + & $t c d A^{-} / t c d B^{+}$ \\
\hline $\mathrm{P} 27 \mathrm{H}$ & + & + & + & $t c d A^{+} / t c d B^{+}$ \\
\hline P29B & + & + & + & $t c d A^{+} / t c d B^{+}$ \\
\hline P29C & + & + & + & $t c d A^{+} / t c d B^{+}$ \\
\hline P77E & + & + & + & $t c d A^{+} / t c d B^{+}$ \\
\hline P77G & + & - & + & $t c d A^{-} / t c d B^{+}$ \\
\hline P77I & + & + & + & $t c d A^{+} / t c d B^{+}$ \\
\hline VPI $10463^{b}$ & + & + & + & $t c d A^{+} / t c d B^{+}$ \\
\hline
\end{tabular}

$a$ : multiplex-PCR detection; $b$ : reference strain $C$. difficile VPI 10463

\section{DISCUSSION}

Clostridium spp. is part of the intestinal indigenous microbiota of young children and they can produce several endogenous infections (Van der Vorm 1999). C. difficile is considered the etiologic agent of PMC and the major cause of antibiotic-associated diarrhea in adults, but the attribution of this organism to enteric diseases in children is less clear (Karlsson et al. 2000).
Studies on C. difficile-associated diarrhea in Brazil have been limited, probably due to the lack of technology and facilities in the culture of anaerobic pathogens. In this study, the prevalence of Clostridium spp. and $C$. difficile, and the toxin production amongst hospitalized children with acute diarrhea and of a control group was investigated.

CCFA medium is recommended for the isolation of $C$. difficile; however, other species of clostridia also grow and produce a characteristic yellow fluorescence under UV light, according to Murray et al. (1995) and Lee et al. (2000).

C. difficile was isolated from $5.5 \%$ of the patients and no healthy children harbored this microorganism. Similarly, Soyletir et al. (1996) found this organism in 4.9\% of Turkish children with diarrhea. In Brazil, Garcia and Uzeda (1988) isolated C. difficile from $13.8 \%$ of clinical samples from hospitalized children with acute diarrhea.

From the 18 hospitalized children with clostridia-positive stool samples, 4 of them were not taking antibiotics at the time of the sampling, but $C$. difficile, C. ramosum, $C$. limosum, C. innocuum, and Clostridium spp. were also recovered. The use of antimicrobial agents can alter the bacterial isolation range; however, no differences in the recovering of clostridia from hospitalized children who were given or not an antibiotic therapy were observed. On the other hand, it is suggested that some factors such as immunological alterations, age, nutritional conditions, genetic factors, pathologies or antimicrobial therapy, can also interfere on the clostridia isolation (Zhang et al. 1999). No other enteropathogenic organism was observed in stool cultures.

The recovery of $C$. difficile in patients with diarrhea could represent a small fraction of their intestinal microbiota, or it could be a fecal-oral contamination (Bressane et al. 2001). In this study, 9 C. difficile were toxigenic to VERO cells, but other isolated clostridia also produced minor tissue alteration. Clostridia produce cytotoxins that alter the eucariotic Rho proteins, producing a cytoskeleton disruption of the intestinal cells and modifying their shape (Lerm et al. 2000). From 37 stool samples positive to clostridia, 30 stool extracts produced alterations on VERO cells; however, it cannot be considered exclusively as caused by $C$. difficile, unless these alterations on cellular culture are neutralized by a specific antitoxin (McVay \& Rolfe 2000).

Both toxins are consistently detected in fecal specimens from human beings and experimental animals; thus, both toxins are produced during the disease period (Lyerly et al. 1985). According to Kato et al. (2001), we also observed that, from 10 isolated $C$. difficile, only 1 nontoxigenic strain lacked the genes for both toxins $\mathrm{A}$ and $\mathrm{B}$, while 6 toxigenic strains carried both toxin genes, and 3 toxigenic strains carried only toxin B gene.

On the other hand, it has been documented that $C$. difficile cytotoxin is inactivated by the myeloperoxidase system of neutrophils and by $\mathrm{H}_{2} \mathrm{O}_{2}$ of Lactobacillus acidophilus (Ooi et al. 1984). According to Niyogi et al. (1991), it may occur the absence of cytotoxic activity in fecal samples due to an in vivo inactivation of the toxin, despite the isolation of toxigenic $C$. difficile in this sample. 
These findings indicate that both $t c d A$ and $t c d B$ or $t c d B$ are stably expressed in $C$. difficile, suggesting that a definitive diagnosis of $C$. difficile infection can be accomplished by a multiplex-PCR detection of the toxin genes, rather than by tissue culture assay or enzyme immunoassay of isolates from stool (Karasawa et al. 1999).

The presence of $C$. difficile as a probable causal agent of acute diarrhea is suggested in several countries. However, our results show that the presence of $C$. difficile was not significant, suggesting that other enteropathogens such as rotavirus, enteropathogenic Escherichia coli, enterotoxigenic E. coli or Vibrio cholerae could be implicated in diarrhoeal processes in Brazil (Bressane et al. 2001).

These results also suggest the need of more studies to evaluate the role of $C$. difficile in diarrhoeal processes, which could provide a better understanding of these infections, in ecological and pathogenic terms.

\section{ACKNOWLEDGEMENTS}

To Mr Cesar A Nascimento, Mrs Fabíola Giancristófaro, and Mrs Zulmira A Souza for their technical support.

\section{REFERENCES}

Banno Y, Kobayashi T, Kono H, Watanabe K, Ueno K, Nozowa $\mathrm{T}$ 1984. Biochemical characterization and biological actions of two toxins (D-1 and D-2) from Clostridium difficile. Rev Infect Dis 6: S11-S20.

Bartlett JG 1984. Treatment of antibiotic-associated pseudomembranous colitis. Rev Infect Dis 6: S235-S241.

Bressane MA, Durigon, LE, Avila-Campos MJ 2001. Prevalence of the Bacteroides fragilis group and enterotoxigenic Bacteroides fragilis in immunodeficient children. Anaerobe 7: $277-281$

Delost MD 1997. Introduction to Diagnostic Microbiology, Mosby, USA, $280 \mathrm{pp}$.

Falk PG, Hooper LV, Midtvedt T, Gordon JI 1998. Creating and maintaining the gastrointestinal ecosystem: what we know and need to know from gnotobiology. Microb Mol Biol Rev 62: 1157-1170.

Freeman J, Wilcox MH 1999. Antibiotics and Clostridium difficile. Microb Infect 1: 377-384.

Garcia LB, Uzeda, M 1988. Ocorrência de Clostridium difficile nas fezes de crianças do Rio de Janeiro, RJ. Rev Inst Med Trop São Paulo 30: 419-423.

George WL, Sutter VL, Citron D, Finegold SM 1979. Selective and differential medium for isolation of $C$. difficile. J Clin Microbiol 9: 214-219.

Gilligan PH, Walden TP, Kelly WF, Wait KJ, Kraft JA, Willis DH 1993. The use of a commercially available enzyme immunoassay for the detection of Clostridium difficile toxin A. Arch Pathol Lab Med 117: 507-510.

Gulke I, Pfeifer G, Liese J, Fritz M, Hofmann F, Aktories K 2001. Characterization of the enzymatic component of the ADP-ribosyltransferase toxin CDTa from Clostridium difficile. Infect Immun 69: 6004-6011.

Holdeman LV, Moore WEC 1977. Anaerobe Laboratory Manual, 4th ed., Anaerobe Laboratory, Virginia Polytech- nic Institute and State University, Blacksburg, 200 pp.

Karasawa T, Nojiri T, Hayashi Y, Maegawa T, Yamakawa K, Wang XM 1999. Laboratory diagnosis of toxigenic Clostridium difficile by polymerase chain reaction: presence of toxin genes and their stable expression in toxigenic isolates from Japanese individuals. $J$ Gastrol 34: 41-45.

Karlsson S, Lindberg A, Norin E, Burman LG, Akerlund T 2000. Toxins, butyric acid, and other short-chain fatty acids are coordinately expressed and down-regulated by cysteine in Clostridium difficile. Infect Immun 68: 5881-5888.

Kato H, Kato N, Watanabe K, Yamamoto T, Suzuki K, Ishigo S 2001. Analysis of Clostridium difficile isolates from nosocomial outbreaks at three hospitals in diverse areas of Japan. J Clin Microbiol 39: 1391-1395.

Knoop FC, Owens M, Crocker IC 1993. Clostridium difficile: clinical disease and diagnosis. Clin Microbiol Rev 6: 251265.

Lee K, Yong D, Yum J, Sohn YS, Chong Y 2000. Modification of cycloserine cefoxitin fructose agar to suppress growth of yeasts from stool specimens. Anaerobe 6: 269-271.

Lerm M, Schmidt G, Aktories K 2000. Bacterial protein toxins targeting Rho GTPases. FEMS Microb Lett 188: 1-6.

Lyerly DM, Saum KE, MacDonald DK, Wilkins TD 1985. Effects of Clostridium difficile toxins given intra-gastrically to animals. Infect Immun 47: 349-352.

McMillin DE, Muldrow LL, Leggette SJ 1992. Simultaneous detection of toxin A and toxin B genetic determinants of Clostridium difficile using the multiplex-polymerase chain reaction. Can J Microbiol 38: 81-83.

McVay CS, Rolfe RD 2000. In vitro and in vivo activities of nitrazoxanide against Clostridium difficile. Antimicrob Agents Chemother 44: 2254-2258.

Murray PR, Baron EJ, Pfaller MA, Tenover FC, Youlken RH 1995. Manual of Clinical Microbiology, 6th ed., ASM Press, Washington, $583 \mathrm{pp}$.

Niyogi SK, Bhattacharya SK, Dutta P, Naik TN, Prakash S, Sen D, Saha RM, Datta D, Nair GB, Mitra U, Bhattacharya M, Rasaily R, Pal C 1991. Prevalence of Clostridium difficile in hospitalized patients with acute diarrhoea in Calcuta. $J$ Diarrhoeal Dis Res 9: 16-19.

Ooi W, Levine HG, LaMont JT, Clark RA 1984. Inactivation of Clostridium difficile cytotoxin by the neutrophil myeloperoxidase system. $J$ Infect Dis 149: 215-219.

Peterson LR, Kelly PJ, Nordbrock HA 1996. Role of culture and toxin detection in laboratory testing for diagnosis of Clostridium difficile-associated diarrhea. Eur J Clin Microbiol Infect Immun 15: 330-336.

Rocha MFG, Sidrin JJC, Lima AAM 1999. O Clostridium difficile como agente indutor de diarréia inflamatória. Rev Soc Bras Med Trop 32: 47-52.

Soyletir G, Eskiturk A, Kilie G, Kortin V, Tozun N 1996. Clostridium difficile acquisition rate and its role in nosocomial diarrhoea at an university hospital in Turkey. Eur $J$ Epidemiol 12: 392-394.

Van der Vorm ER 1999. Gas gangrene in an immunocompromised girl due to a Clostridium ramosum infection. Clin Infect Dis 28: 923-924

Zhang G, Svenungsson B, Karnell A, Weintraub A 1999. Prevalence of enterotoxigenic Bacteroides fragilis in adult with diarrhea and healthy controls. Clin Infect Dis 29: 590-594. 